\title{
Thomas Piketty's Capital and the Developing World Nancy Birdsall*
}

Capital in the Twenty-First Century, Thomas Piketty (Cambridge, Mass.: Harvard University Press, 2014), 696 pp., \$39.95 cloth.

homas Piketty's Capital in the Twenty-First Century is a tour de force-a compelling and accessible read that presents an eloquent and convincing warning about the future of capitalism. Capitalism, Piketty argues, suffers from an inherent tendency to generate an explosive spiral of increasing inequality of wealth and income. This inegalitarian dynamic of capitalism is not due to textbook failures of capitalist markets (for example, natural monopolies) or failures of economic institutions (such as the failure to regulate these monopolies), but to the way capitalism fundamentally works. Unless the spiral is controlled by far more progressive taxation than is now the norm, the political fallout could undermine the viability of the successful "social state" (p. 471) in the advanced economies, putting the democratic state itself at risk.

Piketty's argument and conclusions build on long historical series of data on capital, wealth, income, and tax returns, primarily from the author's native France, the United Kingdom, and the United States. For lack of comparable series for all but a few developing countries, Piketty cannot say much about the dynamics of inequality in the developing world, where almost six of the world's seven billion people live, and where about half of world product is now generated; ${ }^{1}$ nor can he address whether today's thoroughly globalized form of capitalism is fueling global inequality.

In this essay, following a brief summary of Piketty's model, I consider three issues: the relevance for developing countries of Piketty's proposal of more

\footnotetext{
${ }^{\star}$ For thoughtful comments on an initial draft, I am grateful to Alan Gelb, Carol Graham, Nora Lustig, Lawrence MacDonald, Branko Milanovic, and Arvind Subramanian. I also thank Anna Diofasi and Allison Grossman for their excellent research help.
}

Ethics \& International Affairs, 28, no. 4 (2014), pp. 523-538.

(C) 2014 Carnegie Council for Ethics in International Affairs

doi:10.1017/So892679414000653 
progressive taxation of income and wealth in rich countries; the relevance of his model for the global economy over the next several decades; and the relevance of his model and his policy proposal for the broader problem of distributive justice in an unequal global system.

Noneconomist readers may not realize the extent to which Capital has excited and provoked economists, and the variety of reactions it has elicited depending on their prior conception about whether and why high inequality of wealth and income matters for the capitalist model and for social justice. ${ }^{2}$ In this essay I refer to the various technical and data critiques of some of the world's finest economists only in the context of my broader assessment of the book's relevance for the developing world and for our understanding of global inequality.

\section{Capitalism Generates Inequality: The Model}

It is no accident that Piketty titled his book Capital: the book is about capitalism itself and the social and political forces the capitalist system unleashes. It is an extension of Marx into the twenty-first century. Marx focused on the functional distribution of income between capital and labor. Piketty extends that focus to the personal distribution of income and wealth, and especially to the tremendous concentration of wealth at the top centile or 1 percent of the distribution-who, he estimates, controlled 35 percent of the total wealth in the United States in 2010, compared to pretty much zero for the bottom 50 percent of the distribution. ${ }^{3}$ Capital, as he treats it, includes not only the productive capital of textbook economics but also personal assets that are inherited or accumulated by individuals through savings and investment of their labor income, including in real estate. ${ }^{4}$

Noneconomists will find Piketty's argument easy to follow independent of the three mathematical relationships (his "fundamental laws of capitalism") that constitute his model (p. 52). Simply put, as long as the rate of return to all kinds of wealth $r$ (5 percent a year, for example) exceeds the rate of growth of an economy $g$ (1 percent a year, for example), the stock of capital (or wealth) in an economy will increase and the share of capital in national income will grow. As that stock and its income from capital increase relative to total income in an economy, those who own the capital, and those who inherit some of it, need only reinvest enough of it to grow ever wealthier.

Piketty is convincing in his claim that the state of the world in which $r$ exceeds $g$ has been the norm in today's advanced economies for much of the last three 
centuries. The exceptional period, which proves the rule, are the years 1914 to 1980. He documents a dramatic decline in the stock of capital during the two world wars and the interwar period. During and after World War I, inflation and high taxes levied to finance war-related public debt hit hard the wealthiest, especially in Europe. Following World War II, high catch-up growth in Europe and Japan and higher-than-ever growth in the United States (and increased population growth, which contributes to total economic growth) pushed up growth relative to the return to the greatly diminished stock of capital-reversing the historic relationship of $r$ exceeding $g$.

Then came a "Golden Age" in Western Europe, the United States, and Japan-and in the developing world as well (p. 98). Increases in education, economic opportunity, and income created a new middle class; labor-friendly politics and policies and big increases in public spending on health and education added up to the creation of "social states" in the high-income democracies. Capitalism was saved from its inherent dynamic of ever-increasing capital accumulation and concentration of wealth.

Starting around 1980, however, postwar catch-up growth receded; taxes on wealth, income, and inheritances fell with the Reagan-Thatcher revolution; and the increasing "financialization" (p. 193) of the global economy created a hierarchy of returns in which the more capital in your endowment the higher return you could get to that capital. ${ }^{5}$ As a result, Piketty argues, the inequalities that we associate with the traditional class-based nineteenth-century societies of Austen, Balzac, Dickens, and Downton Abbey are reappearing-even in the supposedly classless United States. Up to then, the United States benefited from the constant arrival of new immigrants with zero wealth, making it a "wealth-young" country, ${ }^{6}$ and from the accompanying extraordinarily high population growth (from 3 million at the time of independence to nearly 320 million today, compared to a mere doubling of population in France during the same period). ${ }^{7}$ But by 2010 the only difference between the United States and nineteenth-century Europe was that the top 1 percent had become wealthy due not only to inheritance but to the accumulation of labor income as "supermanagers" in financial and other global industries (p. 265).

\section{Piketty's Policy Proposal: Relevant for Developing Countries?}

Piketty proposes an increase in the progressivity of taxes in the advanced economies as a mechanism to control the inegalitarian dynamic he attributes to the 
capitalist system. For a few countries in the developing world for which he has at least some data on income distribution covering the last century, including China, Colombia, India, and South Africa, he records the same phenomenon of growing inequality and concentration of wealth at the top as in the advanced economies, particularly in the last two decades. ${ }^{8}$ In Colombia and South Africa, Piketty concludes that the top centile captured more than 15 percent of labor income alone in the last decade, similar to the distribution in the United States. ${ }^{9}$ But without tax data except for these few developing countries, Piketty avoids pronouncing on whether the dynamic he laments in advanced economies has or will take hold in other developing countries.

Suppose, however, that the Piketty dynamic already exists or will eventually prevail in developing countries. Would his policy solution make sense for them? Considering that question requires a closer look at why he decries high inequality in the first place.

\section{Piketty's Worry}

Piketty's work is all about inequality of outcomes, not of opportunity. That in itself is refreshing. Because there is no particular level of economic inequality that is inherently too much (few Americans are concerned that Bill Gates is extraordinarily rich), conventional wisdom is that it is inequality of opportunity and not of outcomes that is the fundamental problem. Complete equality of opportunity, it is widely acknowledged, would be good for economic growth, ${ }^{10}$ and moreover is intuitively just and fair. ${ }^{11}$ So most contemporary mainstream economists argue that developing-country policymakers should concentrate on increasing educational and other opportunities for the poor, and not necessarily on wealth redistribution financed by higher or more progressive taxes. ${ }^{12}$

Piketty, however, finds the enormous inequality that he documents deeply problematic in itself. Why? Not because it is a worrying signal of unequal opportunity. ${ }^{13}$ Instead, he fears for the future of the social state that developed in the postwar democracies of the advanced economies. In that sense he is very much an economist with French (not Anglo-Saxon) sensibilities. Nor is his concern that - in the textbook warning-taxes impose deadweight losses on economies (for example, by reducing incentives to work) or that high government spending can be inefficient and wasteful. His concern is political: he worries about the political ability of today's rich democracies, as wealth becomes increasingly concentrated and global, to finance the health, education, and social insurance typical of 
the European social state. (In fact he is at some pains to clarify that he is not arguing for redistribution per se. The "modern redistribution" of today's Western social states is not about "transferring income from rich to poor, at least not in so explicit a way." ${ }^{14}$ )

\section{Piketty's Proposal}

What would Piketty do about inequality and its pernicious effects? He calls for progressive income taxes and, even better, more progressive wealth and estate taxes. ${ }^{15}$ The progressive income tax, he explains, was first invented in the early twentieth century in European countries and in the United States. In the United States it was installed in the Progressive Era of Teddy Roosevelt-not for revenue purposes but to avoid the concentration of wealth associated with the leisure aristocracy of class-ridden Europe. After World War I top marginal income tax rates skyrocketed to almost 80 percent in France, Japan, the United Kingdom, and the United States; in the United States they remained at or above 70 percent until $1980 .^{16}$

What level of fiscal progressivity makes sense? The level, he says, has to be a product of political compromise in democratic states. But he is clear that he favors much higher rates than prevail today. For the United States he proposes a marginal tax rate of 80 percent on incomes of $\$ 500,000$ to $\$ 1$ million a year. An annual wealth tax of 1 percent on fortunes between 1 and 5 million euros, and of 2 percent on fortunes above 5 million, he argues, would do no harm to economies, as today's "immense inequalities of wealth have little to do with entrepreneurial spirit or . . promoting growth" (p. 572). In an interesting diversion from his main story, Piketty argues that it is the reduction of formerly high marginal tax rates beginning in the 1980s that fed the explosion of CEO and Wall Street salaries in the United States once the disincentive that the high rates had formerly created was removed. In other words, the huge increases over the last 30 years in the concentration of labor income (and ultimately wealth) for the top 1 percent and top 0.1 percent of "rentier" supermanagers ${ }^{17}$ is the result not only of winner-take-all forces in a competitive global economy but also of insufficiently progressive tax rates, especially in the United States.

Without a tax assault on the richest 1 percent, he fears other direct and more pernicious attacks on free market capitalism (he makes clear that he favors free market capitalism over far worse systems, such as communism and authoritarian state-run capitalism). Those risks include protectionism; overuse of capital 
controls; increased resistance to immigration; and above all the capture of the political process in advanced democracies by the economic elite, and with it the gradual breakdown of the social state and the democratic system. ${ }^{18}$

Finally, since capital is highly mobile across national borders, he concludes that the ideal, if politically unattainable, tax (what he calls "a useful Utopia") would be a global tax on capital. Such a tax would be global in only one sense: the rate of such a tax would be agreed across countries to prevent arbitrage, but the imposition of such a tax would be meant to control national, not global, spirals of inequality, and the revenue would be collected and spent by each nation.

In short, egregious inequality matters because it puts at risk the democratic politics that undergird the European-style social state. Without healthy politics, market-based capitalism is unlikely to be politically sustained in high-income democratic states. An inegalitarian spiral inherent to capitalism is the Achilles' heel of capitalism; adequately progressive taxation of capital and income (along with regulation of capital and modernization of social programs) is the key to containing the resulting risks to the democratic state and to capitalism itself. High inequality does not matter for growth itself, or even for the sake of fairness or redistribution. It matters for democracy.

\section{Wrong Way Around for Developing Countries}

In the case of developing countries, I would turn Piketty's worry and his proposed policy solution on their heads. Piketty is concerned about a problem that does not exist (at least not yet) in developing countries. For example, most developing countries do not enjoy the open and mature democratic social states that "capitalism," in Piketty's view, is putting at risk. And his policy solution (more progressive taxation and a globally agreed tax on wealth), even if it could be effectively implemented in developing countries, would address a symptom-not the underlying cause-of deeper pathologies that contribute to injustice and inequality in the developing world.

Recall that Piketty argues that the dynamic of ever-increasing inequality in capitalist systems is due neither to textbook imperfections and failures of markets nor to failures of economic and political institutions, but is inherent in capitalism's process of growth itself. The way to control the resulting spiral of inequality is to implement a potent progressive tax policy. A potent progressive tax policy on the part of an active, organized, and democratic social state is critical to preserve-and here there is some circularity-the active, organized, and inclusive 
social state the advanced economies enjoy. But in developing countries the issue is not primarily whether capitalism itself generates inequality unless an effective state intervenes to offset its inegalitarian dynamic. The issue is that too often the inequality is the consequence of the weakness of the economic and political institutions that constitute an effective social state in the first place. ${ }^{19}$ That weakness results in governments having difficulty managing market failures-the market failures that Piketty dismisses as a fundamental cause of the dynamic he describes in the case of the advanced economies.

There are many problems of modern economies that competitive markets alone cannot manage. Industries, for example, have no reason to limit pollution-which imposes costs on others-unless the state regulates or taxes the pollution. Natural monopolies such as power generation companies will easily abuse their pricing power in the absence of state oversight. Unregulated banking and other financial service firms can generate huge systemic risks that ultimately taxpayers may have to cover, as the financial crisis of 2008-2009 illustrated. In addition to regulating markets, states also provide public goods, such as security and defense, and help finance quasi-public goods, such as health and schooling.

States use taxes and regulation to finance public goods and enforce regulatory standards-in the interests of economic efficiency and growth as well as equality of opportunity. But taxes and regulation require a reasonably effective state. Often it is precisely the failure of the state to play that fundamental role effectively that leads to increases in the concentration of wealth and income. The privatization of state-owned enterprises in Russia in the 1990s, for example, was hijacked by insiders. An institutional failure at the political level shortchanged growth and increased dramatically the concentration of wealth. ${ }^{20}$ In Latin America the mining and plantation economies of the colonial era created a politically powerful elite that still endures in some countries, with little interest in creating economic opportunities for the majority of people. ${ }^{21}$ So, too, in Angola, Nigeria, and other oil-rich countries with fledgling democracies. For example, General Sani Abacha of Nigeria accumulated billions of dollars in Europe's banks in the 1990 for lack of any checks on the abuse of his executive power at that time. ${ }^{22}$ In India and China increases in inequality over the last two decades are the result not only of more open and competitive markets; they are also the result of pervasive corruption for the private gain of political insiders. ${ }^{23}$

In short, countries are in the process of developing precisely because their economic and political institutions are underdeveloped; inequality in 
"developing" countries has far more to do with the weakness of economic institutions and the failures of democratic politics than with the relationship between $g$ and $r$. Development, after all, is about building a capable state that is accountable to its citizens-the democratic and social state that the citizens of the advanced economies already enjoy. ${ }^{24}$ Stated simply, the governments of developing countries are often unable-either administratively or politically or both-to tax their citizens sufficiently to finance what Piketty calls the social state. That may be because they lack the political legitimacy critical to collecting taxes; or they lack the capability to deliver the security and infrastructure and social services that are critical to citizens' willingness to pay taxes; or the great bulk of their citizenry is too poor to finance the state through taxes (median income across the developing world, including the largest emerging market economies, is less than $\$ 5$ per person per day, or about $\$ 7,000$ for a family of four ${ }^{25}$ ). The great majority of the poor lack a mechanism to demand the kind of accountable government associated with the idea of a social contract between taxpayers and the state.

A central reality for developing countries is the limited size of a middle class that in advanced economies constitutes the bulwark of democracy, and is at the heart of the creation and maintenance of a social contract forged in the political arena. ${ }^{26}$ In most countries that we label "developing" today the majority of people are poor (well below the poverty lines of the advanced economies). In India and much of sub-Saharan Africa (except South Africa) less than 10 percent of households have consumption levels associated with a reasonable minimum for a middle-class standard of living, and many would be pushed out of the middle class were their tax burden increased. ${ }^{27}$ In Russia, post-Soviet Eastern Europe, Turkey, and some countries in Latin America, the middle class has reached or exceeds 30 percent of the population. Still, in most developing countries-including some of those just listed-a tiny elite dominates political decisions, and often manages to minimize or avoid altogether their own tax obligations. ${ }^{28}$ In Pakistan, fewer than 1 million out of more than 182 million citizens pay any income taxes at all. ${ }^{29}$

In much of the developing world, then, a critical first step in reducing the concentrations of income at the top is building the administrative capability and the political and economic institutions that limit elite capture, exploitation of insider rents, and abuse of executive power. A Piketty tax on wealth, even if it were politically possible and enforceable, would not address these deeper problems. This is 
not to say that tax policies and systems do not matter. Most developing countries rely heavily on consumption and other indirect taxes, which are fundamentally regressive. It is income and property taxes that can be progressive, but require building up and modernizing tax administration. Where increasing the tax burden on the top percent of wealth holders can be implemented (in China, for example, and perhaps Brazil), it would at least provide a sense of justice to the poor and middle classes, and encourage the social cohesion that is critical to maintaining political democracies. ${ }^{30}$

Major development institutions and the development assistance community have paid much less attention to tax systems and policies and the incidence of the tax burden across income groups in developing countries than to priorities for government spending and investment and the incidence of public expenditures. ${ }^{31}$ However, that is changing: the rise of the new middle classes in developing countries; the prospect of windfall revenues from natural resources for many lowincome countries; and the increasing availability of data on the distribution of income in developing countries from household surveys (even with their shortcomings on documenting top incomes) $)^{32}$ are all making a difference. In Latin America, in particular, elites may be ready to support a sensible progressive income or wealth tax, given the alternative model exemplified by Venezuela, based on populism and expropriation; in Chile, Brazil, and Peru the fragile but growing middle classes there would likely support such taxes as well.

Still, for the time being Piketty's policy proposal of higher and more progressive tax rates on income and wealth is even more of a political stretch in developing countries than it is in the richest economies. Even if more progressive taxes were legislated, they would be tough to administer and enforce for lack of information on capital and wealth stocks, and for lack of enforcement capability. That said, Piketty's policy proposal is nonetheless a useful ideal; and I hope that Capital in the Twenty-First Century will help fuel attention to tax (and transfer) progressivity in developing countries, and to its relation to the evolution of social contracts and the creation of the inclusive and democratic states that are at the heart of what development is about.

There is one other way that Piketty's argument is irrelevant to most developing countries. Because they are mostly open economies participating through trade and capital flows in an interdependent global market and are smaller than the advanced economies (China, possibly the largest economy in the world by $2030,{ }^{33}$ could be a future exception), they have less control over 
their own fates. Monetary policy decisions by the United States Federal Reserve made entirely for domestic reasons, such as quantitative easing, generate spillovers that monetary authorities in Brazil and India have to manage. Climate change due to past accumulated emissions of greenhouse gases in the rich world raises risks and costs in the poor world. While some of these spillover problems apply to all small economies, rich and poor, they are worse for countries with weak institutions if only because they have less capability to respond and adjust accordingly.

In short, the rich democracies have built a capable and responsive state on the basis of a social contract forged over many decades of social confrontation and political compromise. That they are mature democracies matters. Economic growth has been accompanied by political growth over several hundred years, creating a virtuous political and economic cycle. In the fast-growing emerging markets-including Brazil, China, and India-economic growth over the last two decades has fortified the potential for that virtuous cycle to kick in. Still, in these and the poorer countries of the developing world, the challenge is not, at least not yet, the one Piketty outlines-that an inherent tendency of capitalism is to generate dangerous inequality that if left unchecked will undermine the democratic social state itself. The challenge is the other way around: to build a capable state in the first place, on the foundation of effective institutions that are democratically accountable to their citizens.

\section{Piketty's Story: Relevant for the World Economy?}

To what extent if any might Piketty's inegalitarian dynamic apply to the global economy as a whole? Might his dismal view of the future of capitalism in the advanced economies apply to the future of globalization, too ${ }^{34}$ The proportion of global product generated in the developing world has increased from 30 percent in 1990 to 50 percent today, and barring unforeseen disruptions could grow to 67 percent by $2030 .{ }^{35}$ With the increasing weight of the fast-growing emerging markets in this century, and as globalization that links national economies to each other intensifies, will global growth $(g)$ exceed the global rate of return to capital ( $r$ ), mitigating Piketty's ominous dynamic of inequality in advanced economies, and saving the global capitalist system we label "globalization"? Put another way, it is certainly plausible that a continuation of catch-up growth in the developing world will keep capital accumulation measured at the global level low (as it 
was in the United States for two centuries), so that the global $r$ will stay below global $g$ (or at least sufficiently below to undo Piketty's model), and the ratio of the capital stock to average annual income will not inexorably rise.

Though the contribution of population growth to total growth of developing countries will decline in this century, reducing the total $g$, it will remain high compared to rich countries (given their low and declining fertility rates) because of the momentum of still-large numbers of young people entering their reproductive years, especially in Africa. In addition, growth per capita could remain highenough to offset in Piketty's model the long-run rate of return to capital of 5 percent that he maintains has prevailed throughout history. China's total growth rate is still above 7 percent a year (and was above 10 percent for several decades); India, Bangladesh, and many countries in sub-Saharan Africa have been growing in the last decade at rates greater than 5 percent. Average growth of the developing world as a whole in the last decade has been 6.3 percent, compared to 1.7 percent in the high-income economies. ${ }^{36}$

How ironic if Piketty's inequality dynamic in the advanced economies, to the extent it is a legitimate concern, is neutralized in this century thanks to growth in the developing world. Might higher growth in developing countries and their convergence to income levels of the richest economies-and deeper integration through trade, capital flows, and movement of people across all borders ${ }^{37}$ delay the onset of Piketty's dynamic not only at the global level but within the rich countries as a group? In that way, might the rise of emerging markets, and globalization itself, rescue the capitalist democratic state ? $^{38}$

\section{Global Inequality and Global Justice}

Still, a larger question looms: that of distributive justice in the face of today's stunning inequality of wealth and income between the richest and poorest countries and people in the world. An estimated two-thirds of total global inequality results not from differences among people in education or talent or merit, but from the lottery of birth: the difference between being born in a richer versus a poorer country. ${ }^{39}$ I have emphasized above that the social state (and justice) that Piketty wants to secure in the rich world is limited in the poor world by poverty and lack of state capability-by institutional underdevelopment itself. Perhaps the greater injustice at the global level is that the limits to progress posed by weak states are abetted and often exacerbated by policies and practices in the rich world: by restrictions 
on immigration, continuing confiscatory exploitation of the earth's atmosphere, tolerance of corruption and tax evasion that hurts poorer countries, and the restricted and costly transfer of medical and other technologies from rich to poor enshrined in global agreements on intellectual property rights.

It is not obvious that redistribution in the form of foreign aid from rich to poor countries is the answer, though it can help if it does not further undermine accountability of fledgling states to their own citizens. ${ }^{40}$ In any event, Piketty's global progressive tax on wealth is not meant to finance global redistribution through aid - to generate revenues that would be pooled to help build and maintain capable social states in the developing world.

How then, in the absence of some sort of global redistributive tax system, can we address the moral challenge posed by the enormous differences in income and well-being between the richest and poorest countries, and between the elite and the marginalized within countries? One response is for citizens of the rich and powerful democracies to argue for changes in domestic tax, climate, migration, and other policies and practices at home that would minimize harm abroad. ${ }^{41}$ A broader response is for globally-minded citizens everywhere to support the institutions and coalitions that together constitute, with all their imperfections, the strengthening and democratization of the global governance system.

Within countries it is the function of the nation-state to provide the basic public good of security of citizens and to use taxes, subsidies, and regulatory powers to offset initial unequal endowments among its citizens-including by providing Piketty's social goods. Across countries there is an analogous function for institutions of global governance to organize the provision and financing of global public goods. There are many encouraging examples of the provision of such goods: the United Nations' peacekeeping operations, the International Monetary Fund's role as lender of last resort, the World Health Organization's work on surveillance standards and cross-border management of infectious and contagious disease (for example, on combating the Ebola virus, so much on the global agenda at the time of this writing), and the World Trade Organization's management of trade disputes. But these and other formal institutions of global governance are far from perfect. They are relatively weak and ineffective compared to the state in advanced democracies; and the financial institutions among them (including the World Bank and the International Monetary Fund) lack the legitimacy of democratic states. For the citizens of the smallest and poorest developing countries, whose interests are poorly represented at the global institutions and who 
are yet most vulnerable to the risks of the spillovers mentioned above, the weak and largely undemocratic nature of formal global governance is itself an unfortunate example of a global distributive injustice.

Fortunately, surveys of attitudes in dozens of countries indicate that citizens everywhere are increasingly aware of the reality of global interdependence and the need for the equivalent at the global level of the kinds of public goods and protection we associate with capable states. Perhaps it is for that reason there has been a spectacular increase in what might be called global citizen action, as seen in the growing number of UN-accredited nongovernmental organizations working across borders, in the increase in public-private coalitions concerned with improving business practices in the interest of greater justice (such as the Consumer Goods Forum), and in the beginnings of a people's climate movement. These provide a counterpoint to the lack of distributive justice at the global level associated with a global economy that is, at its core, a capitalist system.

Piketty's brilliant book does not address the issue of global justice, but it does provoke this question: What is the future of a global capitalist system in which economic opportunities and vulnerabilities are evermore integrated and interdependent, but one without the equivalent of a global state to manage its politics and contain its inegalitarian dynamic? Because Capital in the Twenty-First Century returns economics to politics, it is a reminder that the road to global distributive justice in this century requires finding a way to strengthen legitimate and democratic global governance. ${ }^{42}$

\section{NOTES}

${ }^{1}$ Based on purchasing power parity measures of income (using 2005 International Comparison Project prices, adjusted in real terms to 2010).

2 For contrasting examples, see Cowen and Stiglitz. Tyler Cowen, "Capital Punishment," Foreign Affairs (June 2014), www.foreignaffairs.com/articles/141218/tyler-cowen/capital-punishment. Joseph Stiglitz, "Phony Capitalism," Harper's Magazine, September 2014, harpers.org/archive/2014/09/ phony-capitalism/. Solow and Milanovic provide clear and largely friendly (to Piketty) explications of the economic model. Robert M. Solow, "Thomas Piketty Is Right," New Republic, April 22, 2014, www.newrepublic.com/article/117429/capital-twenty-first-century-thomas-piketty-reviewed. Branko Milanovic, “The Return of 'Patrimonial Capitalism': Review of Thomas Piketty's Capital in the 21st Century," World Bank Policy Research Working Paper 6974, July 2014, papers.ssrn. $\mathrm{com} /$ sol3/papers.cfm?abstract_id=2470234aq. On the technical side, Lawrence Summers, among others, questions Piketty's assumption that more and more capital can be substituted for labor without a reduction in the rate of return that is sufficient to offset the rate at which capital is increasing, and his assumption of a constant or rising savings ratio with increasing wealth. Lawrence H. Summers, “The Inequality Puzzle," Democracy Journal, no. 31 (2014), www.democracyjournal.org/33/the-inequality-puzzle.php. On this issue, raised by many economists, the question is the extent to which the assumption of a law of diminishing returns to any one factor of production applies to the case of "capital" as Piketty defines it, which includes real estate and financial capital to the extent it is not allocated to economically productive uses. Chris Giles, in a series of online articles in the Financial Times, raised questions about the data and its presentation. For a summary and comment on the data issues, 
see John Cassidy, "Forces of Divergence," New Yorker, March 31, 2014, www.newyorker. com/magazine/2014/03/31/forces-of-divergence.

${ }^{3}$ See his table 7.2. More recent estimates by Saez and Zucman suggest that the top 1 percent's wealth share was about 40 percent in the United States in 2012, with the top 10 percent owning close to 75 percent of total wealth. Emmanuel Saez and Gabriel Zucman, "The Distribution of U.S. Wealth, Capital Income, and Returns Since 1913," Working Paper (2014).

${ }^{4}$ James K. Galbraith, "Kapital for the Twenty-First Century?," Dissent, Spring 2014, www.dissentmagazine.org/article/kapital-for-the-twenty-first-century.

${ }^{5} \mathrm{He}$ illustrates this point using data on the average real rates of return in the last thirty years to U.S. university endowments of different sizes (table 12.2).

6 Milanovic, "The Return of 'Patrimonial Capitalism."”

7 So that the New York settings of Henry James and Edith Wharton novels were an exception, restricted largely to the Europe-looking and striving upper middle class of the East Coast.

${ }^{8}$ He argues strenuously for developing countries making available whatever tax data they have. "Clearly, household surveys, which are often the only source used by international organizations (in particular the World Bank) and governments for gauging inequality, give a biased and misleadingly complacent view of the distribution of wealth" (p. 330).

9 See Facundo Alvaredo and Julia Landino Valez, "High Incomes and Personal Taxation in a Developing Economy: Colombia 1993-2010," Commitment to Equity Working Paper No. 12, 2013. They report that the top 1 percent of the income distribution accounted for over 20 percent of total income in 2010, on the basis of tax data.

${ }^{10}$ Economists have not always agreed even on equal opportunity being efficient from the point of view of fostering growth. Kaldor, for example, argued that the rich (for whatever reason, including inheritance and luck) are those who provide the savings for investment that fuels growth. Nicholas Kaldor, "A Model of Economic Growth," The Economic Journal 67, no. 268 (1957), pp. 591-624.

${ }^{11}$ It is easier for those on the political right, for example, to agree on the idea of public financing of basic education and health services to promote equal opportunity, than on direct redistribution of income through taxes on the rich to make transfers to the poor.

${ }^{12}$ A good example is World Bank, World Development Report 2006: Equity and Development (Washington, D.C.: World Bank, 2005), econ.worldbank.org/external/default/main?pagePK= 64165259\&theSitePK=469372\&piPK=64165421\&menuPK=64166093\&entityID=000112742_20050920 110826. There is now increasing attention among economists to the possibility that under many circumstances inequality hurts growth (Andrew Berg, Jonathan D. Ostry, and Charalambos G. Tsangarides, "Redistribution, Inequality, and Growth," IMF Staff Discussion Note, International Monetary Fund, April 2014, www.imf.org/external/pubs/ft/sdn/2014/sdn1402.pdf), including by limiting consumption demand except for the richest, as seen recently in the United States. See, for example, Michael Kumhof, Romain Rancière, and Pablo Winant, Inequality, Leverage and Crises: The Case of Endogenous Default, IMF Working Paper, November 2013, www.imf.org/external/ pubs/ft/wp/2013/wp13249.pdf.

${ }^{13}$ In a 2001 article in this journal I wrote that inequality matters in an instrumental sense for three reasons; namely, its negative effects on: growth and poverty reduction; the healthy political processes that underpin the social contract; and the social cohesion required for effective collective decision-making. Nancy Birdsall, "Why Inequality Matters: Some Economic Issues," Ethics \& International Affairs 15, no. 2 (2001), pp. 3-28. Piketty's worry is about the second of those, with allusions to the third.

${ }^{14}$ See p. 479. His approach is essentially Rawlsian. He cites Jefferson's 1776 Declaration of Independence, the 1789 French Declaration of Rights of Man and the Citizen, and Amartya Sen's capabilities approach as well as Rawls's difference principle. The state is responsible for ensuring these rights in a manner that "is in the interest of those with the fewest initial rights and opportunities" (p. 480). A sense of his moral compass and his economic instincts and political affinities is evident in allusions to lost "hope of a just social order"; to high returns to massive accumulations of capital being well beyond what would be "socially productive"; to his annoyance with the tendency of winners in today's United States to ascribe their winnings to the just rewards of a meritocracy; and to his insistence in the concluding chapter that economics as a social science has a normative and moral purpose.

${ }^{15}$ Key to his contribution is the evidence in Part One of the book of the high capital/income ratios and their maintenance in capitalist systems. Because it is the high ratio of capital stock to average annual income that feeds the high concentration of wealth, it is individuals' capital (wealth) whose accumulation should be limited.

16 See figure 14.1., p. 499.

17 See p. 276 for use of the term "rentier." 
${ }^{18}$ Martin Gilens and Benjamin I. Page, based on quantitative analysis of attitudes of the American public on 1,779 policy issues, conclude that economic elites have a dominant influence on U.S. government policy. See Martin Gilens and Benjamin I. Page, "Testing Theories of American Politics: Elites, Interest Groups, and Average Citizens," Perspectives on Politics, no. 3 (2014), pp. 564-81.

19 Acemoglu and Johnson, in their review, emphasize the role of institutions in explaining the fundamental determinants of concentration of wealth. Daron Acemoglu and James Robinson, "The Rise and Fall of General Laws of Capitalism," Working Paper, Massachusetts Institute of Technology, August 2014, economics.mit.edu/files/9834.

${ }^{20}$ For a study on the impact of privatization on equity, including the Russian case, see Nancy Birdsall and John Nellis, "Winners and Losers: Assessing the Distributional Impact of Privatization," World Development 31, no. 10 (2003), pp. 1617-33. For a detailed account of the Russian privatization experience, see Bernard Black, Reinier Kraakman, and Anna Tarassova, "Russian Privatization and Corporate Governance: What Went Wrong?," Stanford Law Review 52, no. 6 (2000), pp. 1731-808.

${ }^{21}$ Even today, public funding of education in most of the region remains skewed to elite public universities, to which the poor have little chance of admission on the basis of "merit" (admittedly an exaggerated version of the tendency everywhere, including in the United States and Piketty's France). Stanley L. Engerman and Kenneth L. Sokoloff, Factor Endowments, Inequality, and Paths of Development Among New World Economics, National Bureau of Economic Research Working Paper 9259, October 2002, www.nber.org/papers/w9259.

${ }^{22}$ David Pallister and Peter Capella, "British Banks Set to Freeze Dictator's Millions," Guardian, July 7, 2000, www.theguardian.com/uk/2000/jul/o8/davidpallister?INTCMP=ILCNETTXT3487\&guni= Article:in\%2obody\%2olink.

${ }^{23}$ For a discussion on the link between political favors and private sector campaign funding in India, see Devesh Kapur and Milan Vaishnav, "Quid Pro Quo: Builders, Politicians, and Election Finance in India," Center for Global Development Working Paper 276, updated March 29, 2013, www.cgdev. org/publication/quid-pro-quo-builders-politicians-and-election-finance-india-working-paper-276updated. On wealth accumulation by China's political elite, see David Barboza, "Billions in Hidden Riches for Family of Chinese Leader," New York Times, October 25, 2012, www.nytimes.com/2012/ 10/26/business/global/family-of-wen-jiabao-holds-a-hidden-fortune-in-china.html?pagewanted=all\& $\mathrm{r}=0$, as well as Jamil Anderlini, "China's Rich Lawmakers Power Ahead," Financial Times, March 4, 2014.

${ }^{24}$ In his latest book, Francis Fukuyama raises the question whether the political order in the United States is now deteriorating. See Sheri Berman, "Francis Fukuyama's 'Political Order and Political Decay,” New York Times, September 11, 2014, www.nytimes.com/2014/o9/14/books/review/ francis-fukuyamas-political-order-and-political-decay.html.

${ }^{25}$ See Nancy Birdsall, Nora Lustig, and Christian Johannes Meyer, The Strugglers: The New Poor in Latin America?, SSRN Scholarly Paper (Rochester, N.Y.: Social Science Research Network, August 8, 2013), papers.ssrn.com/abstract $=2364642$. We, estimate median consumption at about $\$ 3$ in the developing world; household survey data for most countries are on consumption (net of consumption taxes) and of direct transfers; about $\$ 5$ is a very rough estimate of disposable income per day. On the burden of taxes net of transfers for low-income people in developing countries, see Nora Lustig, Carola Pessino, and John Scott, "The Impact of Taxes and Social Spending on Inequality and Poverty in Argentina, Bolivia, Brazil, Mexico, Peru, and Uruguay: An Overview," CEQ Working Paper 13, Center for Inter-American Policy and research, April 2013, www.commitmentoequity.org/publications_ files/CEQWPNo13\%2oLustig\%2oet\%2oal.\%2oOverview\%2oArg,Bol,Bra,Mex,Per,Ury\%2oApril\%202013. pdf.

${ }^{26}$ That is why recent reports of the World Bank, the African Development Bank, and the Asian Development Bank have focused on the question of how big the middle class is in their borrowing countries. For estimates of the size of the middle class in some developing countries, using per person daily income of $\$ 10$ a day, see Nancy Birdsall, "The Rich and the Rest, Not the Poor and the Rest," Center for Global Development Working Paper 207, March 26, 2010, www.cgdev.org/ publication/indispensable-middle-class-developing-countries-or-rich-and-rest-not-poor-and-rest.

27 Using \$10 per person, per day standard. See preceding endnote.

${ }^{28}$ Alberto Alesina, Guido Cozzi, and Noemi Mantovan, in "The Evolution of Ideology, Fairness and Redistribution," Economic Journal 122, no. 565 (2012), pp. 1244-61, make the point that the tax rates are endogenous to views about inequality and justice in a society, and in turn determine the evolution of inequality and wealth.

29 See "Plugging Leaks, Poking Holes," Economist, December 8, 2012, www.economist.com/news/asia/ 21567999-who-will-pay-pakistans-state-plugging-leaks-poking-holes. 
${ }^{30}$ In her review of Francis Fukuyama, Political Order and Political Decay: From the Industrial Revolution to the Globalization of Democracy (New York: Farrar, Straus and Giroux, 2014), Sheri Berman refers to growing public distrust of the state in the United States, leading to the state being very starved of resources. See Berman, "Francis Fukuyama's Political Order and Political Decay."

${ }^{31}$ The World Bank has for decades regularly conducted country expenditure reviews; the IMF provides technical assistance to countries primarily on tax administration. Recent research at the IMF has addressed the incidence of taxes and the implications for inequality. See Berg, Ostry, and Tsangarides, "Redistribution, Inequality, and Growth."

32 This is not to say that household survey data are not more useful for many purposes, and especially for measuring poverty or that tax data are ideal. Piketty's tax data for advanced economies is weak on incomes for the bottom 20 percent of the population (who may not file tax returns) and refers to market not disposable income (after transfers for example), and is for individuals not households. My thanks to Branko Milanovic for reminding me that household survey and tax data are both needed for the full picture.

${ }^{33}$ In purchasing power terms (2005). See Arvind Subramanian, Eclipse: Living in the Shadow of China's Economic Dominance (Washington, D.C.: Institute of International Economics, 2011), table 4.3, p. 87; This is consistent with other reports, including PricewaterhouseCoopers' "World in 2050: The BRICs and Beyond: Prospects, Challenges, and Opportunities" (2013).

${ }^{34}$ Milanovic, "The Return of 'Patrimonial Capitalism," raises this question.

35 The developing world's proportion of global product increased from 30 percent in 1990 to about 50 percent today (measured in 2005 purchasing power parity terms) and barring unforeseen disruptions could grow to 67 percent by 2030 as per capita income in China, India, Brazil and other large emerging markets converges with per capita income in the United States and other advanced economies. Subramanian, Eclipse; International Monetary Fund, "World Economic Outlook Database," September 2011, www.imf.org/external/pubs/ft/weo/2011/02/weodata/weorept.aspx?sy=1990\&ey= $2010 \& \operatorname{scm}=1 \& \mathrm{ssd}=1 \&$ sort $=$ country\&ds $=. \& \mathrm{br}=1 \& \mathrm{prr} 1 . \mathrm{x}=67 \& \mathrm{pr} 1 . \mathrm{y}=1 \& \mathrm{c}=001 \% 2 \mathrm{C} 110 \% 2 \mathrm{C} 2 \mathrm{Oo} \& \mathrm{~s}=\mathrm{PPPSH}$ \&grp $=1 \& \mathrm{a}=1$.

${ }^{36}$ World Bank, World Development Indicators 2014 (World Bank, 2014), publications.worldbank. org/index.php?main_page=product_info\&cPath=o\&products_id=24674.

37 Nancy Birdsall, "Global Markets, Global Citizens, and Global Governance in the Twenty-first Century," in Franklin Allen et al., Towards a Better Global Economy: Policy Implications for Citizens Worldwide in the 21st Century (New York: Oxford University Press, 2014) pp. 427-86.

${ }^{38}$ Charles Kenny, Getting Better: Why Global Development Is Succeeding-And How We Can Improve the World Even More (New York: Basic Books, 2011).

39 Branko Milanovic, Global Income Inequality by the Numbers: In History and Now, World Bank Policy Research Working Paper 6259, November 2012, p. 19, elibrary.worldbank.org/doi/pdf/10.1596/ 1813-9450-6259.

$4^{\circ}$ Angus Deaton, The Great Escape: Health, Wealth, and the Origins of Inequality (Princeton, N.J.: Princeton University Press, 2013). On an approach to foreign aid that maximizes accountability of recipient governments to their own citizens, see Nancy Birdsall et al., Cash on Delivery: A New Approach to Foreign Aid (Washington, D.C.: CGD Books, 2010).

${ }^{41}$ Owen Barder and Petra Krylova, "The Commitment to Development Index: 2013 Edition," Center For Global Development, September 2013, www.cgdev.org/initiative/commitment-developmentindex/index.

${ }^{42}$ Nancy Birdsall, Christian Meyer, and Alexis Sowa, "Global Markets, Global Citizens, and Global Governance in the 21st Century," Center for Global Development Working Paper 329, June 24, 2013, www.cgdev.org/publication/global-markets-global-citizens-and-global-governance-21st-centuryworking-paper-329-0. 